\title{
MELANCOLIA E ALTERIDADE NOS TRISTES TRÓPICOS BRASILEIROS: CLAUDE LÉVI- STRAUSS LEITOR DE JEAN DE LÉRY ${ }^{1}$
}

\section{Melancholy and alterity in brazilian Tristes Tropiques: Claude Lévi-Strauss reader of Jean de Léry}

\author{
Amilcar Torrão Filho*
}

\begin{abstract}
RESUMO
Em 1955 Claude Lévi-Strauss publica seu Tristes Tropiques, um livro de "anti-viagem", que, entretanto, segue os passos do relato de Jean de Léry, Histoire d'un voyage faict en la terre du Brésil, de 1578, seu breviário do etnógrafo. Considerado por ele o primeiro, senão também o último etnógrafo, o que viu a um Paraíso em seus últimos momentos antes da destruição, LéviStrauss herda de Léry a visão melancólica do encontro entre culturas.
\end{abstract}

Palavras chave: Jean de Léry; Lévi-Strauss; Viajantes; Literatura de Viagem

\begin{abstract}
In 1955, Claude Levi-Strauss published his Tristes Tropiques, a book of "anti travel" which, however, follow the steps in the story of Jean de Lery, Histoire d'un voyage faict in the terre du Brésil, published on1578, its ethnographer's breviary. Considered by him the first, but also the last, ethnographer, who saw a
\end{abstract}

1 Este texto é resultado de estágio pós-doutoral realizado na Universitat Politècnica de Catalunya, em Barcelona (2013/2014) que contou com financiamento da Fapesp (Processo 13/06954-6). Realizado também no marco do projeto PAPIIT IG400113 da Universidad Nacional Autónoma de México.

* Professor do PEPG em História da PUC-SP. Líder do Grupo de Pesquisas Núcleo de Estudos da Alteridade. 
Paradise in his last moments before the destruction, Lévi-Strauss inherits from Léry his melancholic vision of the encounter between cultures.

Keywords: Jean de Léry; Lévi-Strauss; Travellers; Travel Literature.

\title{
Inútil Paisagem de um Paraíso Perdido
}

\author{
Mas pra quê \\ Pra que tanto céu \\ Pra que tanto mar, pra quê \\ De que serve esta onda que quebra \\ E o vento da tarde \\ De que serve a tarde \\ Inútil paisagem \\ Antonio Carlos Jobim, Aloysio de Oliveira, Inútil Paisagem.
}

Entre 1555 e 1560 os franceses ocuparam a baía da Guanabara na pequena ilha e forte de Coligny, homenagem ao almirante Gaspar de Coligny, marechal de França, que patrocinou a empresa francesa, e que hoje leva o nome de Villegagnon, seu controvertido governador. O cavalheiro de Malta Nicolas de Villegagnon, inicialmente simpático à Reforma, liderou essa incipiente colônia francesa, chamada França Antártica, a partir de uma efêmera utopia religiosa, na qual conviveriam católicos e protestantes em paz no espaço edénico e paradisíaco do Novo Mundo. Jean de Léry foi um dos missionários huguenotes enviados em 1557 por Calvino a pedido de Villegagnon. A convivência não poderia ter sido mais desastrosa, e os calvinistas foram expulsos depois de uma disputa teológico-política sobre a eucaristia, na qual o líder da colônia defende a transubstanciação contra os reformados. Léry nasceu em 1534, em La Margelle, Borgonha, ele era um sapateiro refugiado em Genebra e publica nessa cidade seu relato de viagem, Histoire d'un voyage faict en la terre du Brésil, em 1578, resultado de sua estada na 
Guanabara entre 1556 e 1558, sobretudo dos três meses passados com os selvagens em terra firme. Para ele o Novo Mundo supunha um refúgio contra as guerras religiosas, assim como a possibilidade de conversão dos indígenas. Se por um lado se desfaz a utopia de convivência pacífica entre as duas religiões, Léry experimenta a hospitalidade dos indígenas, quando a imagem do paraíso terrestre ainda prometia uma utopia regeneradora na América ainda não totalmente tocada pelos europeus. A partir dessa utopia perdida e da tristeza por sua perda na narrativa de Léry, Lévi-Strauss propõe uma reflexão sobre a natureza da alteridade, do encontro de culturas e do trabalho do antropólogo estabelecendo uma relação de sua vida e sua obra com a vida e obra de Léry ${ }^{2}$. Desta construção de si pela narrativa de viagem e da leitura que o etnólogo contemporâneo faz do viajante moderno é do que desejo tratar neste artigo ${ }^{3}$.

A natureza edênica é um índice da promessa de felicidade que estimula a construção dessa colônia na baía do Rio de Janeiro. Inicialmente Villegagnon se inspira na "beleza e na fertilidade da parte da América chamada terra do Brasil" para chamar aos reformados, a quem dizia admirar, a participar de seu serviço de Deus nos trópicos ${ }^{4}$. Léry sente um misto de simpatia e pesar pelos indígenas brasileiros; ele segue a tradição de ver na América esse espaço edênico de promissão, no qual vive um povo inocente, o bom

2 Evidentemente há inúmeras diferenças entre Léry e Lévi-Strauss, de como pensam a alteridade, como veem os indígenas, da natureza da melancolia em cada um deles, da historicidade dessas duas experiências. Além disso, é importante ressaltar que entre Léry e Lévi-Strauss há uma imensa tradição de pensamento que terá como tema a melancolia, a relação com a alteridade, que passa por Montaigne, Rousseau, entre outros. Entretanto, nesse artigo pretendo tratar de suas semelhanças, ou seja, de como Lévi-Strauss constrói uma similitude com Léry estabelecendo uma continuidade literária com sua obra. Meu objeto, portanto, é apenas o livro de viagem Tristes Tropiques, escrito com referência direta a Léry, e não a obra de Lévi-Strauss. Para acompanhar essa leitura e suas nuanças e distinções, remeto a LESTRINGANT, Frank. De Jean de Léry a Claude Lévi-Strauss: por uma arqueologia de Tristes Trópicos. Trad. Port. Beatriz Perrone-Moisés. Revista de Antropologia. São Paulo, 43(2): 81-103, 2000. E do mesmo autor, Léry-Strauss: Jean de Léry's History of a Voyage to the Land of Brazil and Claude Lévi-Strauss's Tristes Tropiques. Viator. Medieval and Renaissance Studies, 32: 417-430, 2001.

3 São inúmeras as possibilidades de interpretação destes dois textos tão multifacetados. Minha proposta é ler Léry através da leitura de Lévi-Strauss. Para uma interpretação também comparativa de Tristes Trópicos, neste caso com Michel Leiris, remeto a MASSI, Fernanda Peixoto. O Nativo e o Narrativo. Os Trópicos de Lévi-Strauss e a África de Michel Leiris. Novos Estudos CEBRAP. São Paulo, 33, jul. 1992: 187-198.

4 LÉRY, Jean de. Histoire d'un voyage faict en la terre du Brésil. 2. ed. [1580]. Ed. de Frank Lestringant. Paris: Le Livre de Poche, 2008, p. 107. 
selvagem de tão grande repercussão nos séculos vindouros. Além da frescura dos ares e da boa temperatura, nunca gélidos nem muito frios, que identificam a baía com o Paraíso, "as matas, ervas e campos são sempre verdejantes", assim como seus habitantes parece que beberam da fonte da juventude, "tal é o pouco cuidado que eles têm das coisas desse mundo". Ao mesmo tempo esse aparente Éden tropical alberga um feudo do Diabo na Terra: Léry agradece a Deus ter sido enviado a este país "entre ignorantes de Seu nome e Sua grandeza, mas possuídos de Satã como sua herança", tendo podido manter-se preservado das malícias do Demônio e fiel à fé reformada ${ }^{6}$. Se a comparação e a analogia são estruturas narrativas que dão sentido ao Novo Mundo, o selvagem também constitui para Léry uma comparação com seu mundo dividido pela intolerância religiosa. Se a crueldade e barbárie dos selvagens tupis é evidente, e sua antropofagia é apenas um exemplo, isso faz pensar a Léry no que se passa entre os civilizados europeus, como os usurários que "chupando o sangue e a medula e, por consequência, comendo-lhes todos em vida, tanto viúvas como órfãos e outras pessoas às quais valeria mais lhes cortar o pescoço de uma vez"; fazendo desses desalmados, assim, mais cruéis ainda que os selvagens ${ }^{7}$.

Léry vê nessa ignorância da palavra de Deus, embora acompanhada de aparente inocência e mesmo de bondade, a confirmação de que sua salvação é impossível, uma vez que o Diabo já se apoderou de seu território. Ao final, sua vida nobre lhes faz melhores que os papistas de Villegagnon ou os "Epicuristas e outros apóstatas" que se satisfazem nos prazeres carnais, o seja, os franceses que viviam entre os selvagens mesclando-se com suas práticas bárbaras e fetichistas, dominados pelas necessidades da carne ${ }^{8}$. Ideia já bastante conhecida, para Léry a nudez das índias nunca incita a lubricidade; sua nudez edênica é identificada com a inocência e o desconhecimento do pecado, muito menos perigosa que as pinturas, perucas, roupas "e um sem fim de outras infinitas bagatelas que as mulheres e jovens daqui, imitando-se umas às outras, não se

5 Id., ibid., pp. 211-212.

6 Id., ibid., p. 169.

7 Id., ibid., pp. 374-375.

8 Id., ibid., p. 170. 
contentam jamais", e que são causas de muitos e piores males ${ }^{9}$. O indígena revela a Léry um mundo além das aparências, ele dá a dimensão da superficialidade da cultura europeia, de sua corrupção e degradação; o índio da Guanabara é um espelho que enfrenta ao europeu a sua face mais deturpada e maléfica. Nesse espelho Léry vê refletida não apenas a impossibilidade de utopia multi-religiosa da França Antártica, ele se defronta com a impossibilidade de expansão da Graça divina sobre a Terra. Esse espelho é parte da montagem do que Certeau define como hermenêutica do Outro realizada por Léry. O mundo par-delà, o mundo do selvagem, é o mundo da oralidade que por meio da escritura é reconvertido ao mundo par-deçà, quando, então, o "outro retorna ao mesmo"10.

Apesar de utilizar o selvagem como índice da barbárie encontrada na Europa dividida pelas guerras de religião, Léry não vê na hospitalidade sincera dos ameríndios uma possibilidade de sua salvação. Uma hospitalidade que mesmo desde sua Genebra querida, ao escrever sua Histoire, ainda recorda e anseia: diante das deslealdades de seus compatriotas, a má influência italiana na França, representada por Catarina de Médici, ele afirma que frequentemente "se arrepende de não estar mais entre os selvagens", os mesmos que lhe demostraram "mais lealdade que muitos dos de aqui, os quais, para sua condenação, portam o título de cristãos" ${ }^{11}$. Sua melancolia é que no mundo par-deçà, iluminado pela Graça divina, os cristãos estão divididos e imersos na exploração do homem pelo homem, em guerras fratricidas, no mundo das aparências e das seduções; já o mundo par-delà, ainda que apresentando sentimentos mais nobres, está irremissivelmente condenado à danação eterna: "De maneira que tudo o que concerne à beatitude e felicidade eterna (aquela que cremos e esperamos em um só Jesus Cristo) apesar da aparência e o sentimento que afirmei que eles têm: é um povo maldito e abandonado por Deus" ${ }^{\prime 2}$. Sua melancólica conclusão é que estes homens, ainda que bons, são descendentes da raça maldita de Cam; além disso não conhecem nenhum tipo de escrita, não tendo acesso,

9 Id., ibid., p. 234.

10 CERTEAU, Michel de. L'écriture de l'histoire. Paris, 2002, p. 259.

11 LÉRY, Jean de, op. cit., p. 508.

12 Id., ibid., p. 420. 
portanto, às Escrituras Sagradas e à mensagem do Evangelho, além de não praticarem a piedade, já que não perdoam nunca as ofensas, tal como recomenda a doutrina cristã. Sendo assim, a sua entrada no reino dos céus é impossível, já que foram abandonados por Deus e não foram iluminados pelos raios da Graça, pelo Espírito Santo e pelo Evangelho, abandonados a seus sentidos e à sua cegueira das verdades de Deus ${ }^{13}$. Dessa forma, Léry "concebe a alteridade (otherness) como uma categoria movediça e instável" 14 , ser cristão ou selvagem não significa estar colocados automaticamente no campo da civilização ou da barbárie respectivamente. É possível oscilar de um campo ao outro de acordo com os atos e as ações; portanto, engajados nas guerras de religião e na perseguição aos compatriotas ou vizinhos, os cristãos se colocam no lugar da barbárie, uma barbárie muito maior do que a dos supostos selvagens.

A Guanabara e seus habitantes representam no relato de Léry o exagero da natureza e da criação divina, um jardim de delícias e uma promessa de Paraíso na Terra que, no entanto, pode esconder um verdadeiro inferno em suas entranhas. Em sua descoberta pelos europeus, o Brasil constituiu uma importante mitologia edênica, muito bem descrita por Sérgio Buarque de Holanda em seu Visão do Paraíso; a Ilha Brasil, ou o mito céltico de Hy Bressail ou O'Brazil, que significavam as ilhas afortunadas (1985: 167-168), mescla de concepções bíblicas e pagãs, que ganha corpo em um hemisfério inexplorado, "que os descobridores costumavam tingir da cor do sonho" ", nesse "bricabraque de maravilhas" resultante das "bodas místicas entre o humanismo antigo e o novo mundo" de que trata Lestringant $^{16}$. Promessas de um Paraíso disponível na Terra confirmadas por uma primavera perene, uma temperatura sem grandes variações, frutos saborosos, campos férteis, eternamente verdes ou salpicadas de "flores multicoloridas e olorosas cortadas de

13 Id., ibid., pp. 422-423.

14 JUALL, Scott D. "Beacoup plus barbares que les Sauvages mesmes": Cannibalism, Savagery, and Religious Alterity in Jean de Léry's Histoire d'un Voyage faict en la terre du Brésil (1599-1600). L'Esprit Créateur. 48(1), 2008, p. 69.

15 HOLANDA, Sérgio Buarque de. Visão do Paraíso: os motivos edênicos no descobrimento e colonização do Brasil. 4. ed. São Paulo: Companhia Editora Nacional, 1985, p. 178.

16 LESTRINGANT, Frank. Sous la leçon des vents. Le monde d'André Thevet, cosmographe à la Renaissance. Paris: Presses de l'Université de Paris-Sorbonne, 2003, pp. 195-197. 
copiosas águas (usualmente quatro rios, segundo o padrão bíblico), ora em lugar elevado e íngreme, ora numa ilha encoberta em que mal se conhece a morte ou a enfermidade ou mal algum" $" 17$. Terra sem males que prefigura todas as Utopias; recordemos que a ilustração de Holbein da ilha de Utopus para o livro de Morus teve como modelo a baía de Guanabara, baseada na carta do cartógrafo real Luís Teixeira; e que essa Utopia está também influenciada pelos relatos que fez Vespúcio de sua expedição de reconhecimento da costa americana pertencente a Portugal ${ }^{18}$. A baía faz, assim, uma viagem conceitual deste espaço cada vez mais mitificado, de uma natureza edênica e paradisíaca a uma utopia social, religiosa e colonial, onde a riqueza, a beleza natural, a bondade do clima, a inocência de seus indígenas, prometem a possibilidade de construção de uma sociedade mais justa, uma terra de promissão, algo que marcou profundamente a Jean de Léry e, como veremos, ressoa ainda na tristeza dos Trópicos de LéviStrauss.

Argumentos que confirmam o caráter divino do Novo Mundo para louvar as suas qualidades sagradas e atrair fiéis e missionários, seja para o desfrute das benesses desse jardim de delícias e liberdade, seja como um chamado para lutar contra as forças maléficas em nome da expansão da verdadeira fé. Entretanto, a visão mítica da América tinha a contrapartida de ver nesse Paraíso terrenal um engano satânico: o Novo Mundo seria um feudo do Diabo, um falso Paraíso, ou uma terra inculta que deveria ser transformada em um Jardim do Éden na Terra por meio da conquista. A América era um feudo do Demônio no qual ele dominava os indígenas nativos como um tirano; portanto, a colonização era uma luta épica contra Satanás ${ }^{19}$. Assim as imagens conceituais sobre a América oscilarão entre essa visão do Paraíso redescoberto, onde o milagre "parecia novamente incorporado à natureza; uma natureza ainda cheia de graça matinal, em perfeita harmonia e correspondência com o Criador" ${ }^{20}$, e o engano maléfico

17 HOLANDA, Sérgio Buarque de, op. cit., p. 170.

18 CARVALHO, Anna Maria Fausto Monteiro de. A Baía de Guanabara. Os itinerários da memória. Revista USP. São Paulo: CCS/USP, 30, jun./ago., 1996, pp. 159-180.

19 CAÑIZARES-ESGUERRA, Jorge. Católicos y puritanos en la colonización de América. Trad. esp. Pablo Sánchez León. Madri: Fundación Jorge Juan, Marcial Pons, 2008, p. 22.

20 HOLANDA, Sérgio Buarque de, op. cit., pp. 203-204. 
de uma beleza que esconde a obra de Satã, horto delicioso e lugar da Queda em um mesmo espaço imaginário. As duas posições podem ser vistas ao mesmo tempo em um mesmo autor, como será em Jean de Léry, por exemplo, que em sua "antropologia teológica" terá uma leitura apocalíptica do descobrimento do Brasil ${ }^{21}$.

\section{O Ex-voto da Escritura}

A tristeza de Léry é não poder pagar a hospitalidade de que foi objeto na Guanabara com a possibilidade da salvação de suas almas; e de que os cristãos da Europa perdessem suas almas nas divisões políticas e religiosas. Esse espírito de tolerância, esse aparente relativismo cultural apresentado por Léry repousa sobre uma ambiguidade, segundo Lestringant, um "profundo pessimismo" ou pelo menos, uma "indiferença diante das esperanças de conversão do selvagem" ${ }^{, 2}$. Não se trata de nenhuma maneira de indiferença, tal como defende o historiador francês, mas uma desesperança, uma melancolia e tristeza pela incapacidade de salvação desse Bom Selvagem destinado a ser destruído pelo contato com o europeu sem que sua alma possa alcançar a remissão. Se Léry não está tomado totalmente por uma acédia que lhe impeça crer na possibilidade da salvação da alma, que lhe faça pensar na inutilidade da teologia, ele descobre na sua experiência entre os selvagens que o homem tocado pela fé, ainda assim, é capaz dos piores crimes, assim como o homem inocente e bom não tem garantido seu caminho de salvação. Se Deus e seu caminho de salvação estão preservados na experiência americana do huguenote, ela lhe provoca um pessimismo em relação à conduta humana e à capacidade de determinados grupos, com ou

21 PASCHOUD, Adrien. Les sacralités amérindiennes au prisme de l'écriture préethnographique: l'exemple de Jean de Léry. Travaux de Littérature. Genebra: Droz, XXIV, 2011, pp. 13-14.

22 LESTRINGANT, Frank. Le Huguenot et le Sauvage. L'Amérique et la controverse coloniale, en France, au temps des guerres de Religion (1555-1589). 3. ed. Genebra: Droz, 2004, p. 360. 
sem valores morais elevados, em terem acesso a este caminho de salvação.

A narrativa de Léry se constrói a partir de uma ausência: ausência do selvagem e da vida edênica da Guanabara, ausência da Graça como elemento de salvação deste Paraíso Perdido, ausência da palavra do indígena, como recorda Certeau: qual ex-voto, pergunta ele, "meu escrito endereça, então, à palavra ausente?"23. O ex-voto do discurso de Léry se dirige a uma promessa impossível de ser cumprida, uma salvação sem horizonte, uma tristeza nostálgica de um tempo passado feliz, porém totalmente infrutífero. Uma saudade inconclusa de um passado incompleto, para o qual Léry erige um monumento em seu texto de combate. Se a Histoire d'un Voyage pode ser lida como resultado direto da publicação da Cosmographie Universelle e das Singularitez de la France Antarctique, de André Thevet, e de um debate em torno da verdade histórica e teológica da experiência francesa na América, em disputa entre católicos e protestantes $^{24}$, ou como diz Léry uma disputa entre os que amam a "verdade dita simplesmente" contra os que preferem a "mentira ornada e maquiada de bela linguagem", 25 ela é também um monumento fúnebre às inúmeras virtudes que Léry vê no selvagem mas que, entretanto, apesar de sua crença nos demônios que infestam o mundo atormentando os homens e na imortalidade da alma, esta "semente de religião" 26 , indicando a presença de um sentimento religioso no selvagem, isso não será capaz de impedir a sua queda e a sua destruição, na medida em que não podem, como afirma Léry, fingir ignorância das coisas divinas, tornando sua recusa ao verdadeiro Deus e seus crimes contra a natureza ainda mais imperdoáveis.

E, se como observa Certeau, o relato da Histoire d'un Voyage opera "um retorno de si a si pela mediação do outro" ${ }^{27}$, Léry retrata a tristeza e a melancolia da perdição do selvagem para reconhecer nele mesmo a incapacidade de salvar-lhe, a inevitabilidade da divisão e do

23 CERTEAU, Michel de, op. cit., p. 249.

24 LESTRINGANT, Frank. Le Huguenot et le Sauvage... op. cit., p. 96.

25 LÉRY, Jean de, op. cit., p. 98.

26 Id., ibid., p. 395.

27 CERTEAU, Michel de, op. cit., p. 250. 
ódio entre os cristãos, os limites da Graça divina. Chama a atenção também que Léry opera uma separação entre o selvagem como homem, digno de admiração e respeito por suas qualidades naturais, e o selvagem inconvertível, aferrado a seus costumes diabólicos, cuja salvação é impossível. Nesses "dois indígenas" antagônicos, Léry elabora uma visão dual do homem, ao mesmo tempo criatura divina, resultante do amor do Criador pelo mundo e de Sua Providência, e um pecado original que o mantém aferrado à transgressão, ao vício e ao erro, fazendo do mundo uma sucessão de horrores. Por isso esse pêndulo moral no qual se balança o homem na "teologia" de Léry, indo da virtude ao pecado negando até mesmo o poder da Graça em redimir o cristão totalmente. No mundo par-deçà, o cristão sofre da mesma dualidade que o selvagem de par-delà, ao ter acesso à Palavra da verdadeira fé, ao ser abençoado pela Graça, ao mesmo tempo em que é incapaz de viver em paz com seus semelhantes, "comendo-se" uns aos outros de maneira ainda mais vil e selvagem do que os indígenas.

\section{A Melancolia dos Tristes Trópicos}

A identificação do indígena e do Brasil com a melancolia e a tristeza retorna com a publicação em 1929 do então célebre Retrato do Brasil. Ensaio Sobre a Tristeza Brasileira, de Paulo Prado. Outra vez uma terra paradisíaca revela um devir de perdição: em uma terra radiosa, diz o autor, vive um povo triste, com uma melancolia legada pelos descobridores que a revelaram ao mundo, os portugueses, gente rude que obedecia a dois impulsos, a ambição do ouro e a sensualidade livre, com a qual se combinará a natureza libidinosa e despudorada do indígena, esse "animal lascivo" 28 . Diferentemente de Léry, em Prado o retorno ao paganismo da Renascença libera o

28 PRADO, Paulo. Retrato do Brasil. Ensaio sobre a tristeza brasileira. 10. ed. rev. e ampl. São Paulo, 2012, p. 52. 
homem às "ambições de poderio, de saber e de gozo"29. Neste falso Paraiso só restam a luxúria e a degradação para o intelectual paulista: "Paraíso ou realidade, nele se soltara, exaltado pela ardência do clima, o sensualismo dos aventureiros e conquistadores. Aí vinham esgotar a exuberância da mocidade e força e satisfazer os apetites de homens a quem já incomodava e repelia a organização da sociedade europeia" $^{30}$. E ao contrário do teólogo calvinista, para Prado a nudez indígena não tinha nada de inocente, o "clima, o homem livre na solidão, o índio sensual, encorajavam e multiplicavam as uniões de pura animalidade. A impressão edênica que assaltava a imaginação dos recém-chegados exaltava-se pelo encanto da nudez total das mulheres indígenas" ${ }^{31}$. A tristeza, junto à luxúria e a cobiça, seriam os traços de formação do Brasil, criado por um povo sem ideais ou preocupação política nem religiosa, mesclado com outras raças por sua luxúria, resultando dessa equação maléfica uma raça triste, saída da "melancolia dos abusos venéreos e a melancolia dos que vivem na ideia fixa do enriquecimento", uma melancolia legada pelo indígena, esse "animal lascivo" e sua propensão diabólica a satisfazer seus apetites carnais. Paixões e tristeza que formavam nossa melancolia racial, na "ausência de sentimentos afetivos de ordem superior", resultante do que o autor identifica a uma tristeza pós-coito, um decaimento físico e moral que se desenvolve nos povos muito sensuais uma propensão à melancolia ${ }^{32}$.

Uma vez mais, a imagem edênica do Brasil tropical, a Visão do Paraíso, se transmuta em um inferno de perdição: não se trata mais da alma do indígena para o cristianismo reformado, mas a alma nacional diante de uma incapacidade de construir uma civilização já que estávamos tomados pela inação da tristeza melancólica. Algo parecido ao que Sérgio Buarque de Holanda apontou como traço que caracteriza o português que nos colonizou, "esse significativo abandono que exprime a palavra 'desleixo' - palavra que o escritor Aubrey Bell considerou tão tipicamente portuguesa como 'saudade' e que, no seu entender, implica menos a falta de energia que uma 
íntima convicção de que "não vale a pena'..."33. Lévi-Strauss em seu período como professor da Universidade de São Paulo nos anos 1930 possivelmente teve contato com essas ideias melancólicas dos intelectuais modernistas brasileiros, lembrando que a primeira edição de Raízes do Brasil é de 1936, quando ainda era professor em São Paulo. Fernanda Peixoto recorda que Lévi-Strauss publicou a maior parte de seus artigos em sua fase brasileira na Revista do Arquivo Municipal e no Boletim da Sociedade de Etnografia e Folclore, que eram órgãos do Departamento de Cultura dirigido por Mário de Andrade, de quem Claude e Dinah Lévi-Strauss eram muito próximos $^{34}$. Entretanto, para ele, não se trata de um ressentimento com uma identidade nacional fracassada, com raízes culturais mal plantadas, como é para seus contemporâneos modernistas, mas uma melancolia que funciona como um procedimento epistemológico que dá sentido ao trabalho do etnólogo diante de dois mundos que desaparecem: o do indígena destruído pelo contato deletério do encontro colonial, do qual o etnólogo em alguma medida faz parte, e do europeu culto, diante da barbárie da guerra mundial e da ascensão do Novo Mundo, ao qual não se sente de todo integrado. Um procedimento metodológico que ele emula claramente da visão melancólica de Jean de Léry diante do Paraíso perdido dos Tupinambá na Guanabara.

Em 1955 Claude Lévi-Strauss publica seu celebrado Tristes Tropiques, um livro de "anti-viagem" segundo o próprio autor, que, no entanto, segue os passos do relato de Jean de Léry, de quem sempre se sentiu próximo, literária e pessoalmente, já que foram os dois em algum momento de suas vidas exilados pela perseguição religiosa e política. Em realidade, esse livro não pode ser lido sem se ter em conta a leitura que ele faz da obra de Léry. Para Lestringant a Histoire d'un voyage "atravessa em filigrana Tristes Trópicos, legível de ponta a ponta nessa viagem em palimpsesto" 35 . Apesar dessa filiação a Léry, ou mesmo por causa dela, o autor inicia seu livro com a conhecida frase "Odeio as viagens e os exploradores", pela qual se

33 HOLANDA, Sérgio Buarque de. Raízes do Brasil. 20. ed. Rio de Janeiro, 1988, p. 76. 1998 , p. 92.

34 PEIXOTO, Fernanda. Lévi-Strauss no Brasil: a formação do etnólogo. Mana, 4(1),

35 De Jean de Léry a Claude Lévi-Strauss, op. cit., p. 84. 
separa da aventura, que não tem cabimento no trabalho do antropólogo, ou melhor dizendo é um agregado indesejável, um mal necessário. Tampouco lhe interessa essa "escória da memória", as descrições das pobres recordações do itinerário ${ }^{36}$, os pequenos acontecimentos e fatos pitorescos que são parte importante dos relatos de viagem. A aventura e a paisagem jogam um papel depreciativo em Lévi-Strauss; é o que ele critica nos livros de viagem, uma "preocupação pelo efeito" que quer dar o sentido do valor do testemunho do autor do relato, quase sempre não mais do que lugares comuns e banalidades "milagrosamente transmutadas em revelações" pelo simples fato de terem sido "santificadas por um percurso de vinte mil quilômetros" ${ }^{37}$. Lévi-Strauss se insurge contra a descrição dos acontecimentos do itinerário, as dificuldades do caminho que aproximam a narrativa do viajante etnógrafo da aventura, aquilo que nos relatos faz com que o leitor "possa apreciar o valor do testemunho que eles trazem"38, negando assim o papel da anedota em seu relato, que é um recurso central da literatura de viagem. A anedota é aquilo que produz um efeito de verdade por meio de um testemunho do mundo em primeira pessoa, produzindo uma evidência pessoal de verdade. No entanto, Lévi-Strauss considera essa interferência do pessoal e do aventureiro como um desvio de rota, uma traição descritiva que impede um olhar reflexivo diante do mundo do selvagem ${ }^{39}$. A anedota é um micro relato, uma interrupção temporal no relato espacial do itinerário que insere a subjetividade do narrador

36 LÉVI-STRAUSS, Claude. Tristes tropiques. Paris, 2005, pp. 9-10.

37 Id., ibid., p. 10.

38 Ibid.

39 Jean Maugüé, professor de Psicologia na USP e companheiro de Lévi-Strauss, comenta a sua postura reflexiva a analítica diante do indígena às margens do Araguaia, entre os Karajá: "Lévi-Strauss logo começou a trabalhar, sentado sobre o mesmo solo que os indígenas, procurando se fazer entender, lançando perguntas, tomando notas. Eu me maravilhava vendo que ele podia decifrar gestos dos quais Courtin e eu não podíamos pegar senão o pitoresco". Les Dents Agacées. Paris: Buchet-Chastel, 1982, pp. 118-121. Apud PEIXOTO, Fernanda, op. cit., p. 93, tradução da autora. A insurgência de Lévi-Strauss contra o anedótico e o pitoresco no contato com o indígena corresponde a esse esforço de decifração de sua alteridade descrito nesse depoimento de Maugüé, para quem a compreensão do mundo do indígena não ia além do efeito anedótico e superficial. 
viajante $^{40}$; sua utilização é uma maneira de dar uma "impressão de verdade" à narrativa, ao mesmo tempo em que o coloca na "via da literatura de ficção" ${ }^{41}$. Ela implica uma porosidade do relato de viagem bem como uma inversão da posição do observador, tornado protagonista de uma narrativa na qual o observado torna-se secundário na construção de uma trama que exige a performatividade do exotismo para produzir sentido. Ao insurgir-se contra o exotismo, que coloca o selvagem no âmbito do pitoresco, Lévi-Strauss não pode conceder um droit de cité ao anedótico. Sendo assim, seu relato de viagem descompõe o gênero da viagem, não apenas pela sua proposição inicial irônica e provocadora de seu ódio à viagem, mas pelo questionamento de seus procedimentos narrativos.

Por outro lado, a anedota não deixa de estar presente nas deambulações de Lévi-Strauss pela baía de Guanabara, pela cidade do Rio de Janeiro, por sua "não" descrição de uma paisagem já por demais narrada, tópica frequente na literatura de viagem desde o século XIX. Sua aversão à viagem tampouco é novidade no gênero, já que outra tópica frequente era a separação entre o verdadeiro viajante e o turista ingênuo e ignorante ${ }^{42}$, sensível apenas ao pitoresco e ao exotismo dos mundos visitados. Ao definir-se como não viajante, como aquele que odeia a vulgaridade da viagem sem propósito filosófico, tal como apregoavam os viajantes filósofos da Ilustração setecentista, e muitos filósofos sedentários, Lévi-Strauss se coloca ao lado da verdadeira viagem, representada por sua filiação a Léry, um verdadeiro, e talvez último, viajante, aquele que viajou com um propósito epistemológico, promover a convivência pacífica das religiões e salvar o selvagem, ele também vindicador de uma verdade viajora em relação às deturpações e mentiras de papistas como André Thevet. A filiação é em relação a Léry e não mais a nenhum outro viajante, nem mesmo Montaigne, pois para Lévi-Strauss Léry foi a a

40 LINON-CHIPON, Sophie. Certifiquata Loquor. Le rôle de l'anedocte dans les récits de voyage (1658-1722). In: GOMEZ-GÉRAUD, Marie-Christine, ANTOINE, Philippe (dirs.). Roman et récit de voyage. Paris: Presses de l'Université de Paris-Sorbonne, 2001, p. 201.

41 Id., ibid., p. 193.

42 URBAIN, Jean-Didier. L'idiot du Voyage. Histoires de touristes. 2. ed. Paris: Payot, 2007, pp. 32-33. Cf. KUBICA, Grazyna. Lévi-Strauss as a protagonist in his ethnographic prose: a cosmopolitan view of Tristes tropiques and its contemporary interpretations. Etnográfica. 18(3), 2014, p. 609. 
primeira e última testemunha do Paraíso, o iniciador involuntário de um procedimento de reconhecimento da alteridade praticamente morto no momento mesmo de sua criação. Não por acaso Certeau vê na narrativa Léry a construção de uma figura da modernidade, um dispositivo que define um regime de verdade moderno que se relaciona com novas experiências do mundo, uma "mise en scène científica", ou uma "ciência de sonhos" que formam um discurso sobre o outro, a circunscrição de uma das regras do sistema ocidental e moderno: "a operação escriturária, que produz, preserva, cultiva 'verdades' não perecíveis, se articula sobre um rumor de palavras evanescentes no momento mesmo que são enunciadas, perdidas, assim, para sempre"43. A filiação a Léry, portanto, não é apenas literária ou biográfica, mas também conceitual, por uma filiação a uma concepção de mundo que deseja ir além das aparências e da aventura para a compreensão da alteridade do Novo Mundo. Por isso Kubica pode definir Tristes Tropiques como um "livro de viagem antropológico", ou como um exemplo de prosa etnográfica ${ }^{44}$.

A viagem também lhe causa outro tipo de melancolia, a de encontrar por todo o mundo os "subprodutos maléficos" do Ocidente que infectam a terra: "O que primeiro nos mostras, viagens, é o nosso lixo atirado na cara da humanidade" 45 . A viagem recorda ao etnógrafo o caráter entrópico de sua cultura e seu potencial destrutivo, o que lhe faz afirmar que em lugar de antropologia deveríamos chamar a essa disciplina "entropologia", dedicada a estudar em suas manifestações mais altas esse processo de desintegração que é a vida humana ${ }^{46}$. A etnografia coloca o europeu diante da própria presença de "uma vertigem da melancolia" que faz ressurgir "desse horizonte da morte" a "presença efêmera e fascinante do outro" 47 , mediada pela tristeza saudosa do primeiro cronista desta "variante degradada do Éden" 48 que é o Brasil. Para Lestringant, tanto em Léry quanto em LéviStrauss há uma "beleza do morto", uma consciência do

43 CERTEAU, Michel de, op. cit., pp. 248-249.

44KUBICA, Grazyna, op. cit., p. 601; p. 604.

45 LÉVI-STRAUSS, Claude, op. cit., p. 36.

46 Id., ibid., p. 496.

47 LESTRINGANT, Frank. De Jean de Léry a Claude Lévi-Strauss, op. cit., p. 98

48 Id., ibid., p. 93.

49 Id., ibid., p. 100. 
desaparecido. A literatura de viagem, pelo menos aquela representada pelo breviário de Léry, funciona na construção de Tristes Tropiques como um memorial, um recordatório do mundo desaparecido, o exvoto de que trata Certeau, ou um epitáfio do selvagem. O selvagem real é apenas aquele descrito pelo narrador do Paraíso, enquanto os Cadiueu, os Bororo, os Nambiquara ou os Tupi-Cavaíba descritos pelo etnógrafo não são mais do que ruínas de povos remanescentes, fósseis degradados pela civilização predatória de homens outrora livres e bons. Lévi-Strauss e, de certa forma, Léry, se defrontam nessa destruição com a obra de sua própria civilização; cada qual à sua maneira chorará o luto de uma morte: teológica para o huguenote, ou cultural para o antropólogo, bem como as exéquias de uma civilização ocidental que pouco a pouco se descompõe.

Daí que sua memória etnográfica utilize como efeito para a importância de seu relato o testemunho primordial desse primeiro observador do Paraíso que foi Léry, que viveu o momento "das verdadeiras viagens" e foi, portanto, um verdadeiro viajante, que viu um mundo que ainda não estava "contaminado e maldito",50, sobrando ao viajante contemporâneo buscar os restos, os "vestígios de uma realidade desaparecida" ${ }^{251}$. Embora sua melancolia seja justamente ser ele, o etnógrafo moderno, o observador de um mundo que desapareceu e ao qual só se pode aceder por meio do relato do huguenote calvinista e do qual não nos resta muito mais do que o efeito da paisagem, essas "imagens inelutavelmente falsas que nos dão as viagens por fatalidade" $" 52$. Um pessimismo lucreciano diante do mundo, segundo Susan Sontag, que entende o conhecimento como "consolidação e imprescindível desencanto". Para Lévi-Strauss o demônio é a história, diz Sontag, pois o passado, "com suas estruturas misteriosamente harmoniosas, se quebra e desmorona diante de nossos olhos. Daí que os trópicos sejam tristes" ${ }^{\text {"53 }}$ ou como afirma em seguida, não só são tristes, como agonizam ${ }^{54}$. A história é o que leva o

50 LÉVI-STRAUSS, Claude, op. cit., p. 42.

51 Id., ibid., p. 43.

52 Id., ibid., pp. 10-11.

53 SONTAG, Susan. El antropólogo como héroe. In: Contra la interpretación y otros ensayos. Trad. esp. Horacio Vásquez Rial. Barcelona, 1984, p. 89.

54 Id., ibid., p. 97. 
selvagem ao caminho da destruição e da extinção, portanto, a "antropologia é necrologia" em Lévi-Strauss segundo Sontag: temos que estudar aos primitivos antes que desapareçam ${ }^{55}$. Para essa autora, ele e seus discípulos se rendem ao "melancólico espetáculo do desmoronamento do passado pré-histórico" $"$.

\section{A Viagem como Viático}

Desse espetáculo melancólico do desmoronamento de um passado resulta que Viveiros de Castro defina Tristes Tropiques como o "relato de um trabalho de campo malogrado", livro pós-moderno antes do tempo ${ }^{57}$, que também afronta a nostalgia de um mundo que caminha para o desaparecimento, um "impasse biológico, planetário, cosmológico"; a consciência de que talvez sejamos a única espécie que se vai se extinguir sabendo-o, ainda que não queira $\operatorname{acreditar}^{58}$. A nostalgia, ou a tão lusitana saudade, é uma das afecções que une no tempo a Histoire d'un voyage e os Tristes Tropiques; Léry lamenta não estar mais entre os selvagens, mais civilizados que os assim chamados cristãos, enquanto Lévi-Strauss lamenta as saudades de um mundo que desapareceu antes mesmo de poder conhecê-lo. Não por acaso titulará a seus dois livros de fotos Saudades do Brasil, publicado na França com o título em português, e Saudades de São Paulo, publicado unicamente no Brasil; as saudades não são exatamente do espaço brasileiro percorrido em seus anos de formação, mas têm relação com o sentimento de perda, o aperto no coração ao recordar um determinado lugar, quando somos "penetrados pela evidência de que não há nada no mundo de

55 Id., ibid., p. 89.

56 Id., ibid., pp. 89-90.

57 CASTRO, Eduardo Viveiros de. Claude Lévi-Strauss por Eduardo Viveiros de Castro (entrevista). Estudos Avançados. São Paulo: IEA, 23(67), set./dez, 2009, p. 194.

58 Id., ibid., p. 200. 
permanente e estável em que apoiar-se"59. Saudades dos Brasis, não exatamente as diversas paisagens brasileiras visitadas pelo etnógrafo, mas os indígenas, chamados os Brasis pelos cronistas e viajantes entre os séculos XVI e XVIII. Esses indígenas caracterizados por sua abertura ao outro, cujo pensamento ameríndio transformado se transmutou em seu estruturalismo, de quem seriam também autores os Brasis $^{60}$.

Entre Léry e Lévi-Strauss lhes une um sentimento de perda e de luto por um mundo dividido pelas guerras e pela intolerância, o desencaixe de ambos, fugidos das perseguições religiosas e políticas, e um deslocamento em relação a sua própria época. Lévi-Strauss confessa que a leitura de Léry lhe ajudou, "a escapar de meu século, a ter contato com o que posso chamar uma surrealidade", não aquela dos surrealistas, mas "uma realidade ainda mais real que aquela da qual fui testemunha", porque vista pela primeira vez ${ }^{61}$, pouco tempo depois de iniciada a sua destruição ${ }^{62}$. Em Léry já está colocada também essa distância de sua própria civilização, por aquilo que define o trabalho do etnógrafo para Lévi-Strauss: por suas condições de vida e de trabalho que lhe retiram fisicamente de seu grupo por longos períodos, pela brutalidade de mudanças às quais se expõe, ele "adquire uma espécie de desarraigo crônico: nunca jamais ele se sentirá em casa em nenhuma parte, ele permanecerá psicologicamente mutilado" ${ }^{63}$. A surrealidade, essa realidade impressa no relato fundador de Léry, ainda que fundador de uma tradição natimorta, substitui a realidade em estado bruto, da violência e da destruição, da qual ambos, Léry e Lévi-Strauss, procuram fugir por meio de sua operação de escritura, de fixar no relato aquilo que interessa à etnologia, o que não está escrito, "as condições inconscientes da vida social", diz Lévi-Strauss, essa escritura que percorre a oralidade e sabe o que ela diz, segundo Certeau ${ }^{64}$, diferentemente da história que

59 Saudades de São Paulo. Apud PERRONE-MOISÉS, Beatriz. Os Brasis em LéviStrauss. Diacrítica, Filosofia e Cultura. Braga: Universidade do Minho, 23(2): 57-73, 2009, p. 63 60 PERRONE-MOISÉS, Beatriz, op. cit., p 67.

61 LÉVI-STRAUSS, Claude, op. cit., p. 13.

62 Id., ibid., p. 63.

63 Id., ibid., p. 57.

64 CERTEAU, Michel de, op. cit., p. 246. 
se ocupa do que está registrado, do mundo consciente do homem ${ }^{65}$. Esta meta-realidade é produzida, em Tristes Tropiques, a partir da leitura de Léry, cujo livro será, para Lévi-Strauss, o seu "breviário do etnógrafo" $"$.

A que breviário se refere o etnógrafo? Ao guia de trajeto, ao modelo, tão comum na literatura de viagem à qual não quer se filiar o autor, uma instrução viática que educa o olhar do viajante? Ao livro preferido, ao livro de doutrina? Ou ao livro de preces contendo o essencial de uma liturgia? Léry funciona como guia e roteiro de viagem a Lévi-Strauss tanto pelo espaço da Guanabara, na qual simbolicamente se iniciou o processo de destruição do Paraíso e pelo qual, deambulando, Lévi-Strauss reflete sobre o fim melancólico do mundo do selvagem, como no tempo, evadindo o etnógrafo do presente ao passado, no qual ele pode ser testemunha do momento exato antes da Queda, uma promessa de felicidade retrospectiva. Tal como o anjo de Benjamin, Lévi-Strauss volta o rosto para o passado coberto de ruinas, mas vislumbrando um lampejo de felicidade perdida na vida selvagem anterior ao encontro, ou ainda em seus momentos iniciais. Não deixa de ser, portanto, um ofício fúnebre, o viático dos viajantes e o viático que é o sacramento dos mortos, daqueles que já morreram com Léry e daqueles que morrerão sem remissão, juntamente com Lévi-Strauss. Apesar de seu "ódio" pela viagem, é por meio dos relatos de viajantes, de Bougainville, de Léry, que ele pode desafiar o tempo histórico e ter acesso a esse mundo no momento do encontro. "Cada lustro para trás", diz o antropólogo, "me permite salvar um costume, ganhar uma festa, compartilhar uma crença suplementar". Não lhe resta outra alternativa que ser um viajante moderno "correndo atrás de vestígios de uma realidade desaparecida"67. Curiosamente é pela História, que ele tantas vezes opôs aos interesses e métodos da antropologia, que Lévi-Strauss recupera o mundo do indígena, na medida em que a maior parte dele

65 LÉVI-STRAUSS, Claude, História e Etnologia. In: Antropologia Estrutural. Trad. port. Beatriz Perrone-Moisés. São Paulo: Cosac \& Naify, 2008, p. 32: "A história organiza seus dados em relação às expressões conscientes, e a etnologia, em relação às condições inconscientes da vida social.

66 LÉVI-STRAUSS, Claude, Tristes Tropiques, p. 87.

67 Id., ibid., p. 59. 
está irremediavelmente perdida e só temos acesso a ele por meio de documentos e vestígios do passado. É pela viagem, que ele renega, ou por Léry instituído como documento, que ele pode recompor a alteridade do selvagem, ao mesmo tempo cultura viva apreensível pela observação direta, fóssil de uma era geológica desaparecida e documento de barbárie do encontro de culturas. Ex-voto ao qual se dirige, por meio do breviário do etnógrafo, o seu discurso, o seu relato de viagem.

\section{Triste Guanabara}

Confrontado com o espaço americano, o mesmo visitado e descrito por Léry no século XVI, a paisagem americana jogará um papel ambíguo no texto do etnógrafo: ela é definida por ele como uma "imensa desordem, que dá liberdade de escolher o sentido que queiramos the dar" ${ }^{68}$. Como descrever uma paisagem como a Guanabara depois de definir de forma tão ambígua e complexa o papel da paisagem na percepção de um espaço e de uma realidade social? Lévi-Strauss é consciente desse problema e se questiona sobre ele. A América lhe dá uma impressão de enormidade que lhe define um sentimento de deslocamento, de desorientação, de incongruência do tamanho do homem em relação às coisas. Assim, a cidade do Rio de Janeiro the propõe um problema, na medida em que ela lhe "rechaça apesar de sua beleza tantas vezes celebrada", pois lhe parece que sua paisagem "não está à escala de suas próprias dimensões". Seus pontos de referência mais conhecidos, o Corcovado, o Pão de Açúcar "parecem ao viajante que penetra a baía como restos de dentes perdidos nos quatro cantos de uma boca banguela". Perdidos nas brumas tropicais esses acidentes geográficos não chegam, afirma, a "mobiliar um horizonte demasiado grande para ser contido"69. O Novo Mundo, se em algum momento lhe inspirou, como a Léry, uma 
esperança de renovação e refúgio, se torna subitamente em profunda incompreensão e deslocamento. Mesmo tentando fugir da viagem e de suas escórias, Lévi-Strauss reproduz a experiência de estranhamento e repulsa de toda uma tradição de narrativas de viagem $^{70}$. Seu Tristes Tropiques recompõe os elementos fundadores presentes no livro de Léry, a nostalgia e o remorso, emoções inseparáveis do trabalho etnológico, segundo Lestringant ${ }^{71}$.

Para Lévi-Strauss a baía é uma sinédoque da cidade, ela a representa em sua impossibilidade de compreensão, de abarcá-la com o olhar e com os conceitos de que dispõe o viajante moderno e europeu. Ao contrário de Nova Iorque, que lhe serviu de exemplo de como os conceitos europeus de cidade não servem para apreciar as cidades americanas, o Rio deveria ser olhado das alturas por uma "ilusão inversa àquela de Nova Iorque", quando seria a natureza quem daria "o aspecto de um canteiro" que se tem na cidade estadunidense desde o alto de seus arranha-céus ${ }^{72}$. Ao contrário das descrições clássicas da baía, da chegada dos navios a seu porto, da percepção dos acidentes geográficos que lhe definem um contorno, essa escória da memória que já havia criticado, Lévi-Strauss para apreciar a cidade do Rio deve dar-lhe as costas e olhá-la desde o espelho da Guanabara. E se a baía representa a cidade, a paisagem que tanto esforço cobra do etnógrafo para ser decifrada revela também outra substância, a de um continente que se impõe, que lhe "envolve e esmaga"; para além da diversidade das coisas e dos seres, o que se impõe é "uma só e formidável entidade: o Novo Mundo"73. Novo Mundo como entidade geográfica, a América que se impõe, e como entidade temporal e histórica, o futuro que este América prepara e representa, que

70 Cf. TORRÃO FILHO, Amilcar. Inútil Paisagem: Memória e Utopia na Baía de Guanabara, de Jean de Léry a Lévi-Strauss. In: FAU/USP. Espaços Narrados: a construção dos múltiplos territórios da língua portuguesa. São Paulo, 2012. E TORRÃO FILHO, Amilcar. Memoria y utopía en la bahía de Guanabara. De Jean de Léry a Lévi-Strauss. In: DEPETIS, Carolina, CURIEL RIVERA, Adrián (orgs.). Geografías literarias de América. Mérida: Universidad Nacional Autónoma de México, 2015, pp. 49-88.

71 LESTRINGANT, Frank. The Philosopher's Breviary: Jean de Léry in the Enlightenment. Trad. ingl. Katharine Stripe. Representations. 33:200-211, 1991, p. 202.

72 LÉVI-STRAUSS, Claude, op. cit., p. 85.

73 Id., ibid., pp. 85-86. 
substituirá o mundo tal qual o etnólogo conhece, ainda que caminhe, como ele próprio demonstra, para a sua melancólica superação ${ }^{74}$.

Seu capítulo IX está dedicado à baía e se titula Guanabara. A cidade do Rio é "mordida por sua baía até o coração". Cidade e baía quase se canibalizam, como os Tupinambá de Léry e seus inimigos. Aqui também a memória de seus antepassados viajantes se imiscui no texto, pois a primeira fundação da baía, recorda, leva ainda o nome de seu fundador, Villegagnon. A cidade propriamente dita, a Avenida Rio Branco, é o espaço onde antes "se elevavam as tribos tupinambá", desaparecidas do espaço mas presentes em seu bolso, no relato de Léry. O que poderia indicar uma descrição da baía, que em realidade está feita no capítulo anterior, é um resumo do livro de Léry e de suas "aventuras". Se a baía era una sinédoque da cidade, aqui também o relato de Léry é una sinédoque da baía e da própria experiência do etnólogo neste Éden decaído que é a Guanabara. Pois o que deseja o etnógrafo na cidade do Rio, diz ele, é justamente recuperar "o sabor dessa história que eu busco compreender". Ele participa de uma excursão arqueológica organizada pelo Museu Nacional, a uma praia pantanosa donde se oxidava um velho navio encalhado, que não datava certamente do século XVI, da época de Léry, mas era capaz de introduzir "uma dimensão histórica nesses espaços onde nada mais ilustrava a passagem do tempo"75.

A Guanabara aqui se transforma outra vez em uma sinédoque do Novo Mundo, e do Brasil, promovendo uma melancolia pelo desaparecimento daquele mundo visto por primeira vez por Léry que ele tinha vindo buscar no Brasil, mas que já não podia mais que ver seus restos e compará-los com seu breviário guardado em seu bolso. $\mathrm{O}$ encontro com uns pedaços de cerâmica tupi, num local que ele próprio define como "um lugar melancólico", onde Léry talvez tenha "matado o tempo" diante dos objetos feitos pela "mão morena" do indígena, "cujo enigma hoje eu interrogo no reverso de um fragmento empapado" $"$, se transforma no que Susan Silver chama de um

74 Apontamos rapidamente a semelhança de sua interpretação da América com a de Tocqueville em seu A Democracia na América, igualmente melancólico, por motivos diferentes, com a ascensão dos Estados Unidos.

75 Id., ibid., p. 91.

76 Id., ibid., pp. 92-92. 
"momento Proustiano" que une o século XX ao XVI, além de fechar a brecha "entre a expedição de Léry e a chegada de Lévi-Strauss ao mesmo lugar 400 anos depois"77. Esse encontro constitui uma união entre esses dois mundos definida pela melancolia da perda, à qual a história ou a paisagem não servem de consolo. Para Silver, LéviStrauss pensa a antropologia como "uma prática inerentemente melancólica", na qual "a realidade constantemente retrocede e é impossível de capturar" ${ }^{\circ 7}$. Essa realidade só existe no texto de Léry, a realidade material da Guanabara, do Rio de Janeiro, dos indígenas do interior do Brasil não tem substância nem existência concreta no relato dos Tristes Trópicos de Lévi-Strauss. A única realidade possível é aquela entesourada na visão primeva do huguenote borgonhês.

A paisagem aqui é uma atmosfera, e a Guanabara uma representação de uma sociedade e de uma distância histórica entre dois mundos, não mais separados pelo exotismo, que morreu com o desaparecimento da verdadeira viagem, mas por uma separação social que tende a desaparecer, e uma distância temporal, representada pela decadência da civilizada Europa e a ascensão de um Novo Mundo na América, à custa do desaparecimento do mundo Tupinambá descrito por Léry, resultado do encontro destrutivo de duas culturas. Mas representa também a melancolia de uma natureza que se sobrepõe ao homem e que prescinde totalmente dele e de sua cultura, uma decadência rousseauniana que nos prepara para a queda e o nada. $\mathrm{Na}$ Guanabara Lévi-Strauss descobre na paisagem triste a nostalgia de um paraíso perdido, destruído pelo contato deletério das culturas, de una civilização europeia que se desmonta sobre os escombros de sua autodestruição, substituída pela promessa de um Trópico que se levanta até as cimas do mundo civilizado, não mais um Éden na terra, mas um jardim de una ensolarada tristeza.

77 SILVER, Susan. Cannibalism, nudity, and nostalgia: Léry and Lévi-Strauss revisit Brazil. Studies on Travel Writing. 15(2), jun., 2011, p. 125.

78 Id., ibid., p. 125. 


\section{O Breviário de um Epílogo}

A Histoire d'un Voyage já tinha funcionado antes como um breviário do Bom Selvagem ilustrado, servindo de inspiração, ou mesmo sendo plagiado, pelo pseudo-Coréal, pelo abade Raynal ou por Prévost, breviário do filósofo, como define Lestringant ${ }^{79}$. Léry é um "guia, iniciador e quase um irmão mais velho para o viajante moderno" $" 80$ o etnógrafo que não deseja ser viajante. Em que pesem as imensas diferenças entre os dois momentos históricos, entre a natureza da tristeza e do pessimismo de ambos, da tradição de descrição da alteridade e do selvagem que existe entre Léry e LéviStrauss, o etnólogo francês constrói uma identidade comum, uma relação direta com o huguenote de Genebra que transcende o tempo histórico. Lévi-Strauss estabelece uma ponte entre a tristeza e o pessimismo de Léry e a melancolia do antropólogo moderno, construindo uma genealogia dos Tristes Trópicos que vem da oportunidade perdida da criação de uma verdadeira etnografia, quando o mundo era jovem e fresco, o selvagem ainda não havia sido tocado pela mão destrutiva do homem branco e da civilização, iniciando o trabalho fúnebre do antropólogo, de fornecer o viático ao moribundo indígena, de recordar ao mundo e às civilizações que, ao contrário do que pensava Léry, eles não são nem eternos nem haverá nenhuma redenção mística. Tendo um "acentuado gosto pelos inícios", como declara na entrevista que abre a edição moderna da Histoire d'un Voyage ${ }^{81}$, Lévi-Strauss constrói essa correspondência cronológica e histórica entre a obra de Léry e a sua, montando a partir daí uma genealogia da antropologia, ou uma genealogia do encontro das culturas e da alteridade que supõe o campo conceitual da antropologia. Aqui começa "a juventude de uma disciplina" ${ }^{, 2}$, com tantas promessas não cumpridas, tão poucos ex-votos oferecidos.

79 LESTRINGANT, Frank. The Philosopher's Breviary... op. cit., p. 209.

80 Id., De Jean de Léry a Claude Lévi-Strauss... op. cit., p. 86.

81 LÉVI-STRAUSS, Claude, Sur Jean de Léry. Entretien avec Claude Lévi-Strauss. In: LÉRY, Jean de. Histoire d'un Voyage... op. cit., p. 6.

82 LESTRINGANT, Frank. Léry-Strauss: Jean de Léry's History of a Voyage to the Land of Brazil and Claude Lévi-Strauss's Tristes Tropiques. Viator. Medieval and Renaissance Studies. Los Angeles: University of California, Los Angeles, 32, 2001, p. 417. 
Como recorda Lestringant, o pessimismo de Léry leva-o a ler anúncios apocalípticos nos mitos cosmogônicos dos indígenas, enquanto o pessimismo de Lévi-Strauss leva-o a vislumbrar "a sombria serenidade de uma Terra desabitada" ${ }^{\text {"83 }}$. Seu relato de viagem representa, assim, "a decepção do viajante consigo próprio e com sua civilização" $^{\text {" }}$. O mesmo pensava Léry de seus compatriotas; ele se pergunta se podemos condenar totalmente a crueldade dos selvagens antropófagos quando entre os cristãos há criaturas tão abomináveis e mais condenáveis, pois os selvagens só guerreiam as nações inimigas, enquanto os europeus "mergulham no sangue de seus parentes, vizinhos e compatriotas. Não é preciso sair de nosso país nem ir à América, para ver coisas tão monstruosos e prodigiosas" ${ }^{\prime 25}$. No espelho colocado diante do viajante huguenote e do etnógrafo francês, a imagem que reflete à do indígena é a de uma sociedade europeia destrutiva e impiedosa, cada um dos dois vê a sua própria face distorcida, uma autoimagem violenta e terrível. Na ensolarada Guanabara, Lévi-Strauss se defronta com esse espaço onde o tempo histórico não deixou suas marcas, onde só são visíveis as marcas geológicas, as pedras e montanhas que põem o homem em uma escala que não lhe reconhece, na qual ele se perde em sua dimensão diminuta, o que constitui essa constatação melancólica de que o mundo "começou sem o homem e acabará sem ele", e todas as instituições e costumes que Lévi-Strauss passou a vida a inventariar e compreender "são uma eflorescência passageira" 86 , assim como sua vida e sua própria cultura.

Nem Léry nem Lévi-Strauss escapam à sua própria historicidade, nenhum deles deixa de ser homem de seu tempo, com suas contradições e limites, ambos se defrontam com a alteridade marcados pelas fronteiras de sua religião, de seu eurocentrismo, de sua classe, de seu sexo. No entanto, ambos compartilham, e não por acaso Lévi-Strauss enxergou em Léry um próximo e um guia, visões de mundo que colocam em questão elementos de seu tempo, que problematizam e dão complexidade à literatura de viagem e à

83 Id., ibid., p. 428.

84 MASSI, Fernanda Peixoto, op. cit., p. 193.

85 LÉRY, Jean de, op. cit., p. 377.

86 LÉVI-STRAUSS, Claude, Tristes Tropiques...op. cit., p. 495. 
etnografia naquilo que elas compartilham: o confronto do mundo e do Outro que provoca um questionamento das diferenças, dos limites e do valimento da própria cultura e da própria identidade. Ou dito de outra forma, a necessidade de distanciamento e deslocação em relação à própria cultura para compreender a alteridade. Ambos se apresentam como insubmissos às ideias correntes de seu tempo, o que constitui a sua excepcionalidade, ao ultrapassar determinadas medidas de seu tempo: Léry em contra das mentiras e ideias feitas de viajantes que não descreviam o mundo pela observação, enquanto ele, como afirma em seu Prefácio, contava as suas memórias escritas com a tinta do Brasil na própria América, "escrits d'ancre du Brésil",87, bela metáfora de uma escrita que resulta da experiência concreta e referencial do espaço de uma testemunha ocular, uma escritura feita com a tinta da madeira que representa a América, o pau-brasil; feita na terra com matéria da terra. Também pela defesa que faz da humanidade do indígena, sua visão contrária da colonização e da conquista, ainda que não acredite na salvação de sua alma. Da mesma forma, Lévi-Strauss, em sua opção pela etnografia rejeita uma filosofia voltada para si mesma, para a sua coerência interna e sem relações com o mundo exterior ${ }^{88}$, além de sua defesa do selvagem e de seu pensamento. Por outro lado, a autoconstrução como testemunha e texto competente sobre a América realizada por Léry é transformada em uma autoridade etnográfica que transcende seu momento histórico e, portanto, a noção de experiência física, que é fundamental, recorda Andrea Frisch, para "as pretensões científicas da subsequente etnografia europeia". Portanto, a cultura dos nativos brasileiros é mais autenticamente presente em Lévi-Strauss não na experiência do Brasil propriamente, mas no testemunho de Léry ${ }^{89}$.

Ambos retornam transformados da experiência da viagem e da alteridade; Léry sente nostalgia pelos selvagens com os quais não partilhará, no entanto, a salvação da alma, enquanto seus irmãos em Cristo se perdem nas guerras de religião e nas divisões sectárias.

87 LÉRY, Jean de, op. cit., p. 61.

88 DONATO. Eugenio. Tristes Tropiques. The Endless Journey. Modern Language Notes, 81(3), maio, 1966, p. 275.

89 FRISCH, Andrea. In a sacramental mode: Jean de Léry's Calvinist Ethnography. Representations. 77(1), p. 96 
Lévi-Strauss não reconhece mais em seu mundo de origem um lar, uma condição resultante da experiência da viagem prolongada e do ofício do antropólogo, que jamais pode ser neutro em relação a sua própria sociedade. Tendo escolhido esse caminho da etnologia, ele assume que buscou um modo prático de "conciliar seu pertencimento a um grupo com a reserva que ele nutre a seu respeito", marcado por um sentimento inicial de distanciamento, que lhe permite, assim, se aproximar com vantagem de sociedades diferentes da sua ${ }^{90}$. Para chegar ao outro, é preciso afastar-se dos seus, adquirir distanciamento em relação à própria cultura, exercer a crítica em relação a ela. $\mathrm{O}$ trabalho do luto aqui também se refere à morte e à perda, a uma arte de si mesmos ao buscar no Outro uma conexão com aquilo que lhes faltava em sua própria identidade; um reencontro consigo mesmos pela melancólica mediação do moribundo selvagem, viático da própria consciência.

RECEBIDO EM: 12/06/2016 APROVADO EM: 01/12/2016 